\title{
Cations and Anions in Sewage Sludge from Gaza Waste Water Treatment Plant
}

\author{
Ibrahim Y. El-Nahhal', Husam Al-Najar'1, Yasser El-Nahhal' ${ }^{2}$ \\ ${ }^{1}$ Faculty of Civil Engineering, The Islamic University Gaza, Gaza, Palestine \\ ${ }^{2}$ Faculty of Science, The Islamic University Gaza, Gaza, Palestine \\ Email:yel nahhal@hotmail.com
}

Received 7 May 2014; revised 22 June 2014; accepted 6 July 2014

Copyright (C) 2014 by authors and Scientific Research Publishing Inc.

This work is licensed under the Creative Commons Attribution International License (CC BY).

http://creativecommons.org/licenses/by/4.0/

(c) $\underset{\mathrm{EY}}{\mathrm{EY}}$ Open Access

\section{Abstract}

This paper determined cations and anions concentrations, Total Kjeldahl Nitrogen (TKN), and heavy metals content in sewage sludge collected from the drying beds of wastewater treatment plant in Gaza. The aim was to test the possibility of using this sewage sludge as an alternative source of mineral fertilizers. Many instruments were used in this work: flame photometry $(\mathrm{K}, \mathrm{Na})$, EDTA titration (Ca, Mg), the turbidity method $\left(\mathrm{SO}_{4}^{2-}\right)$, spectrophotometer (turbidity), ascorbic acid method (orthophosphate), titrimetric method $\left(\mathrm{Cl}^{-}\right)$, inductive coupled plasma analyzer (ICP, heavy metals). All the processes of experiments and analyses were described clearly for reference. Results showed that concentrations of $\mathrm{Na}^{+}, \mathrm{K}^{+}, \mathrm{Ca}^{2+}$ and $\mathrm{Mg}^{2+}$ were $28.93,2.53,271$ and $177 \mathrm{mg} / \mathrm{kg}$ respectively whereas $\mathrm{PO}_{4}^{3-}, \mathrm{SO}_{4}^{2-}, \mathrm{NO}_{3}^{-}$, and $\mathrm{Cl}^{-}$were $0.434,18.59,0.87$ and $0.026 \mathrm{~g} / \mathrm{kg}$ respectively. The concentrations of $\mathrm{Fe}, \mathrm{Cu}, \mathrm{Pb}, \mathrm{Zn}$ and $\mathrm{Mn}$ were 125.12, 172.56, 76.88, 218.73 and 157.56 $\mathrm{mg} / \mathrm{kg}$ respectively. These results indicate that sewage sludge from Gaza contained high fractions of most plant nutrients accordingly, and it may be advantageous to use the sludge as a natural source of plant fertilizers.

\section{Keywords}

Sludge, Cations, Anions, TKN, Heavy Metals

\section{Introduction}

Gaza Strip (GS) has a coastline of $40 \mathrm{~km}$ at the eastern extreme of the Mediterranean and on the edge of the Sinai Desert. GS has a total area of 365 square kilometers and the population is estimated to be around 1,701,437 
people [1].

Sludge (biosolids) may be defined either the matter which refers to the residual, semi-solid material left from industrial wastewater, sewage treatment plants or settled suspension obtained from conventional drinking water treatment and numerous other industrial processes [2]. Sludge may be dried and incorporated with some carbonaceous materials to produce a suitable composted material for the use in the agriculture to increase the production and improve the soil properties. Chemical and biological compositions of sewage sludge depend on the wastewater composition [3]. Usually, it is rich in Organic Mater (OM) and plant nutrients such as Nitrogen (N), Phosphorus (P) and Calcium (Ca) [4] and can improve soil physical, chemical and biological properties, such as porosity, aggregate stability, bulk density, soil fertility, water movement and retention [5]. There are four wastewater disposal and treatment facilities in Gaza Strip, Beit Lahia, Gaza City, Khan Younis, and Rafah waste-water treatment plants. These stations are not sophisticated treatment technology; they consist of anaerobic lagoons, aerated lagoons and maturation ponds. It is expected that large amounts of sludge are being produced from Gaza Strip wastewater treatment plants.

Furthermore, Casado-Vela et al. [6] monitored the effect of the application of three increasing amounts of composted sewage sludge $\left(3,6\right.$ and $9 \mathrm{~kg} \cdot \mathrm{compost}^{-\mathrm{m}^{-2}}$ ) on the physicochemical properties of a horticultural calcareous soil where two types of plants were grown under two exploitation regimes (one in a greenhouse and the other in open-air). They found out that the $9 \mathrm{~kg} \cdot \mathrm{compost} \cdot \mathrm{m}^{-2}$ application promoted the appearance of deleterious effects on the properties of soil, such as salt accumulation, a significant increase in the electrical conductivity

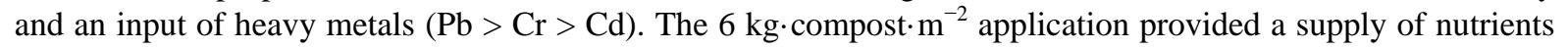
necessary to grow peppers plants under both exploitation regimes.

In a recent study, Roig et al. [7] analyzed the systematic and periodical use, for 16 years, of anaerobically digested sewage sludge as an agricultural fertilizer by assessing the effects on some soil physical-chemical, functional, and ecotoxicological properties. They found that the input of sludge enhances soil properties proportionally to the application doses and/or frequency. In addition, the effects of organic matter, nitrogen, phosphorus and toxic elements in sewage sludge applied to agricultural land were reviewed by [8] and they found that the organic matter may improve the structure and water-holding capacity of poor soils and the nitrogen and phosphorus in sludge have fertiliser value, and the crops can accumulate toxic elements from sludge-amended soils.

In addition, Egiarte et al. [9] examined effect of repeated application of sewage sludge of short-term groundwater contamination and reported that a repeated application of sludge at $60 \mathrm{Mg} \cdot \mathrm{ha}^{-1}$ resulted in significantly higher concentrations of $\mathrm{Zn}, \mathrm{Cd}, \mathrm{Cr}$ and $\mathrm{Ni}$ in the leachates than with other treatments (other loading rates). Moreover, Wong et al. [10] investigated the effects of Dissolved Organic Matter (DOM) from anaerobically digested dewatered sludge on $\mathrm{Cd}$ and $\mathrm{Zn}$ sorption by three different soil types and found that the addition of DOM significantly reduced the $\mathrm{Cd}$ and $\mathrm{Zn}$ sorption capacity for tested soils, suggesting that DOM had a stronger inhibitory effect on $\mathrm{Zn}$ sorption than that of $\mathrm{Cd}$. They also found that the reduction in metal sorption caused by DOM was very apparent in the $\mathrm{pH}$ range of 5 to 8 , with a maximum inhibition on metal sorption occurring at $\mathrm{pH}$ 7 - 7.5 especially for $\mathrm{Zn}$ but the effect was minimal at lower $\mathrm{pH}$.

Khan and Scullion [11] measured the effects of varying sludge metal (Cd, $\mathrm{Cu}, \mathrm{Ni}, \mathrm{Pb}$ and $\mathrm{Zn})$ contents on respiration, biomass $\mathrm{C}$ and $\mathrm{N}$, and $\mathrm{N}$ mineralization in a series of laboratory incubations of soil-sludge mixes. They found that $\mathrm{Cd}$ (up to $70 \mathrm{mg} \cdot \mathrm{kg}^{-1}$ in soil) did not affect any microbial index. Higher concentrations of the other metals generally caused a decrease in biomass $\mathrm{C}$ and $\mathrm{N}$, the reduction for $\mathrm{C}$ often being proportionally less than that for $\mathrm{N}$ and in most cases, higher metal concentrations increased respiration rates and microbial metabolic quotient. In addition to that soil mineral $\mathrm{N}$ was increased by higher inputs of all metals and the use of sludges with higher metal concentrations may lead to short-term changes in soil microbial communities and their activities, with increased loss of $\mathrm{C}$ to the atmosphere and $\mathrm{N}$ availability.

Serna and Pomares [12] determined the N-mineralization rate of 12 sewage sludges in a given soil during a 16-week aerobic incubation by analysis of inorganic $\mathrm{N}$ produced by a nonleached procedure. They found that the aerobically treated sewage sludges gave higher mineralization rates than the anaerobically treated wastes and values of potentially mineralizable $\mathrm{N}$ (No) varied from 71 to $394 \mathrm{mg} \cdot \mathrm{N} \cdot \mathrm{kg}^{-1}$ soil, and mineralization rate constant (k) ranged from 0.089 to 0.883 week $^{-1}$. In a different study, López-Valdez et al. [13] investigated how emissions of $\mathrm{CO}_{2}, \mathrm{~N}_{2} \mathrm{O}$ and $\mathrm{N}_{2}$, and dynamics of mineral $\mathrm{N}$ were affected when different types of $\mathrm{N}$ fertilizer, i.e. $\mathrm{NH}_{4}^{+}, \mathrm{NO}_{3}^{-}$, or unsterilized or sterilized wastewater sludge, were added to the Texcoco soil. It was found that microorganisms added with the sludge accelerated organic material decomposition, increased $\mathrm{NH}_{4}^{+}$immobili- 
zation, and induced immobilization of $\mathrm{NO}_{3}^{-}$(in Texcoco soil). They suggested that wastewater sludge improves soil fertility at Otumba (an agricultural soil) and would favour the vegetation of the Texcoco soil (alkaline saline).

Fytianos and Charantoni [14] investigated the leaching of heavy metals from municipal sewage sludge. They found that for most values of liquid solid ratio $(\mathrm{L} / \mathrm{S})$, the percentage of leached amounts for the examined metals followed the order $\mathrm{Cd}>\mathrm{Zn}>\mathrm{Pb}>\mathrm{Fe}>\mathrm{Mn}$. As $\mathrm{pH}$ decreased, metal concentrations measured in the leachate increased. And in general, EDTA showed the greatest mobilization ability, followed by $\mathrm{NaOH}$, acid solutions $\left(\mathrm{HCl}, \mathrm{H}_{3} \mathrm{PO}_{4}\right)$, and water.

Moreno et al. [15] investigated the effect of sewage sludge amendment of a semiarid soil, previously polluted with Cd, on the toxic effect of this heavy metal on soil microbial biomass and its activity. They found out that in general, higher ED (Ecological Dose) values were calculated for the sewage sludge amended soil than for unamended soil and thus the Cd toxicity to microbial activity of the sewage sludge amended soil can be considered lower than that of the unamended soil. As obvious, very limited data on quantities of sludge are available however, no chemical analysis was done to determine concentrations of cations anions and heavy metal of sewage sludge from Gaza Strip. Accordingly, this study was designed to determine the cations, anions and heavy metals of sewage sludge from Gaza Strip and to test the possibility of using it as an alternative source of mineral fertilizers.

\section{Materials and Methods}

\subsection{Sludge Sampling}

A representative sludge samples with a volume of $20 \mathrm{~L}$ each were collected from different locations from the drying beds in the Sheikh Ejleen Waste Water Treatment Plant.

The samples were air-dried in the month of June 2013 using solar radiation, crushed and mixed together to insure homogeneity of the sludge. The dried sludge samples were sieved through $2 \mathrm{~mm}$ sieve and mixed again and kept in plastic bags for further experimental work.

\subsection{Determination of Cations}

Ten g of sludge samples were suspended in $25 \mathrm{ml}$ distilled water form a ratio of 1:2.5 w/w and shaken over night, the $\mathrm{pH}$ and EC and TDS were measured to each sample. Then additional $25 \mathrm{ml}$ water were added to form a ratio $1: 5 \mathrm{w} / \mathrm{w}$. Nutrient content (K, Ca, $\mathrm{Mg}$, and $\mathrm{Na}$, expressed as $\mathrm{g} \cdot \mathrm{kg}^{-1}$ dry weight basis) were determined by EDTA titration (Ca, Mg), flame photometry (K, Na) [16].

\subsection{Determination of Anions}

The sulfate $\left(\mathrm{SO}_{4}\right)$ was determined using the turbidity method and in this procedure sulfate ion is converted to a barium sulfate suspension under controlled conditions. The resulting turbidity is determined by spectrophotometer at $420 \mathrm{~nm}$ and compared with a curve prepared from standard sulfate solution. While the orthophosphate was determined using ascorbic acid method. The chloride was determined using the titrimetric method by titrating it with silver nitrate $\left(\mathrm{AgNO}_{3}\right)$ in the presence of potassium chromate as indicator

\subsection{Determination of Heavy Metals}

Following the procedure described by [17], the heavy metal concentration in sludge samples will be described. In this procedure, 0.5 - $2 \mathrm{~g}$ air dried sludge were digested in $10 \mathrm{ml}$ of nitric acid $78 \%$ and kept under heating with flux at $65^{\circ} \mathrm{C}$ for $24 \mathrm{~h}$. Then the system was heated up to $120^{\circ} \mathrm{C}$ for another $24 \mathrm{~h}$. After complete digestion (nearly clear solution appeared). The system was left for cooling at the room temperature. The digested sludge was filtered through Whattman scale 43, filter paper ashless. The collected filtrate was completed to the mark of volumetric flask capacity $25 \mathrm{ml}$ with the same acid solution. Then the heavy metals were analyzed using Inductive Coupled Plasma analyzer (ICP).

\subsection{Determination of Nitrogen Fractions}

\subsubsection{Nitrate Fraction}

Nitrate level in the sludge was determined according to the salicylic acid method [18] which converts the nitrate 
concentration under acidic media to the corresponding nitrosalicylic acid with yellow color according to the chemical reactions shown in Figure 1(a).

The intensity of the yellow color represents the nitrate concentration and it was determined using a spectrophotometer. After making a standard curve of nitrosalicylic acid, the same procedure was done to the filtrate from $10 \mathrm{~g}$ of sludge in $50 \mathrm{ml}$ of water. Results were expressed in $\mathrm{g} \cdot \mathrm{kg}^{-1}$ dry weight basis.

\subsubsection{Ammonium Fraction}

Ammonium was determined using Kjeldahl method without the digestion step. Ten ml of the filtrate of $10 \mathrm{~g}$ of sludge in $50 \mathrm{ml}$ of water after shaking overnight were taken to the distillation step of Kjeldahl and then to the back titration step to determine the ammonium fraction using hydrochloric acid. Results were expressed in $\mathrm{g} / \mathrm{kg}$ dry weight basis.

\subsubsection{Determination of Total Organic Nitrogen Fraction}

Organic nitrogen (org-N) was determined using Kjeldahl digestion according to the following procedure below: $0.5 \mathrm{~g}$ of sludge samples were digested with sulfuric acid for 4 hours with $72 \% \mathrm{H}_{2} \mathrm{SO}_{4}$ followed by a second boiling hydrolysis under reflux for 5 hours in $\mathrm{H}_{2} \mathrm{SO}_{4}(0.7 \mathrm{~N})$ until clear solutions were obtained. Then the samples were transferred to the distillation unit at Kjeldahl apparatus to catch the produced ammonium in Boric acid. The ammonium borate was then titrated by $\mathrm{HCl} 0.1 \mathrm{~N}$ to calculate the $\mathrm{N}$ content in sludge samples. The reaction procedures are shown below. Details of chemical reactions are shown in Figure 1(b).

\subsection{Statistical Analysis}

The statistical analysis of data was performed with ANOVA test using Excel program. The samples were in three replicates; mean and standard deviation were calculated. Analysis of variance among treatments was performed using t-test, p-values below 0.05 indicate significant differences.

\section{Results and Discussion}

\subsection{Determination of Sodium, Potassium, Calcium and Magnesium}

Determination of $\mathrm{Na}$ and $\mathrm{K}$ were done using Flame photometer. The relationship between flame-photometer readings of $\mathrm{Na}^{+}$and $\mathrm{K}^{+}$concentrations are shown in Figure 2.

It is obvious that at low concentrations of $\mathrm{Na}$ or $\mathrm{K}$ ions, nearly linear relationship between the flame photometer read and the concentrations. However, fitting the data to a linear regression line showed bad fit $\left(\mathrm{R}^{2}=\right.$ 0.55). Accordingly, converting the data in Figure 2 to a log scale provides good fit. The regression information is shown in Table 1. Where $\mathrm{Y}$ and $\mathrm{X}$ represent the log scales of flame photometer reading and concentrations respectively. Accordingly, the equations in Table 1 were used to determine the sodium and/or potassium concentrations in sludge samples. The measured concentrations are shown in Table 2.

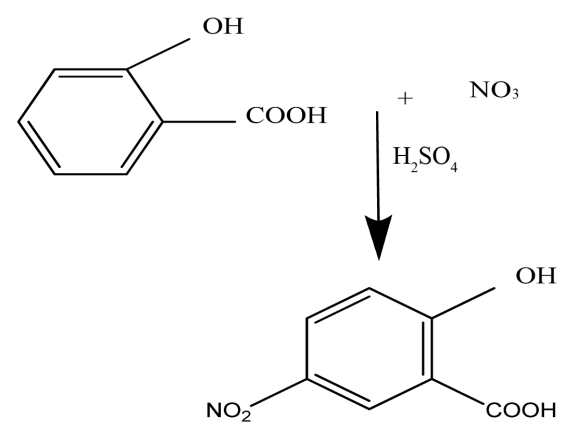

Nitro salicylic acid (yellow color)

(a)

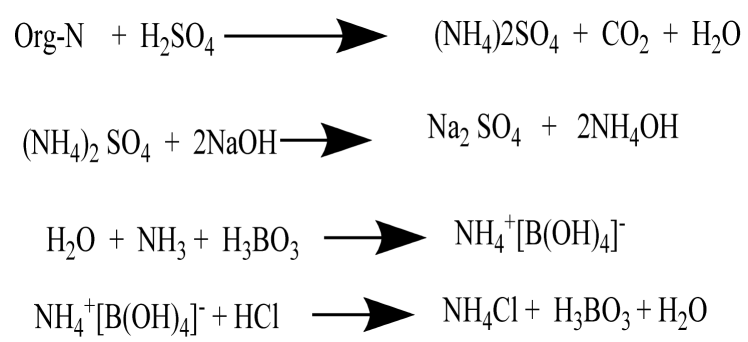

(b)

Figure 1. Conversion of nitrate to nitro-salcylic acid (a); Digestion of organic nitrogen containing compound (b). 


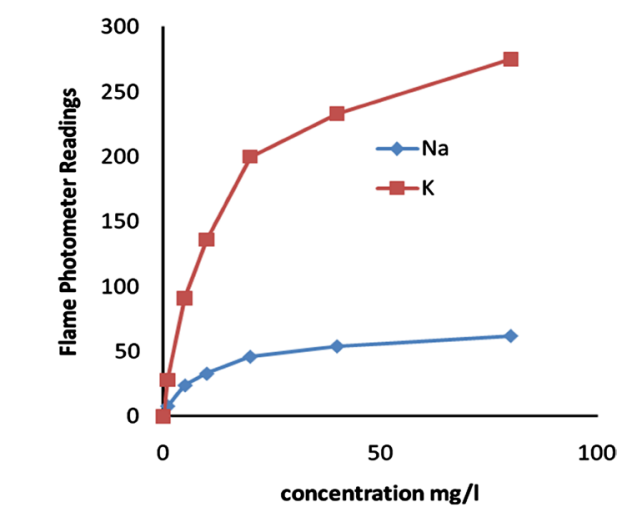

Figure 2. Standard curve of $(\mathrm{Na} / \mathrm{K})$ determination in sludge sample.

Table 1. Regression equations for sodium and potassium.

\begin{tabular}{ccc}
\hline Cation & Regression Eq & $\mathrm{R}^{2}$ \\
\hline $\mathrm{Na}$ & $\mathrm{Y}=2.024 \mathrm{X}+1.95$ & 0.95 \\
$\mathrm{~K}$ & $\mathrm{Y}=1.8093 \mathrm{X}+2.73$ & 0.95
\end{tabular}

Table 2. Sodium, potassium, calcium and magnesium concentrations in sludge samples.

\begin{tabular}{cc} 
Cations & Concentration $\mathrm{mg} / \mathrm{kg}$ \\
\hline $\mathrm{Na}$ & $28.93 \pm 6.85$ \\
$\mathrm{~K}$ & $2.53 \pm 0.43$ \\
$\mathrm{Ca}$ & $271 \pm 38.74$ \\
$\mathrm{Mg}$ & $177 \pm 67$ \\
$\mathrm{Fe}$ & $125.12 \pm 13.65$ \\
\hline
\end{tabular}

Calcium and magnesium concentrations in the sludge samples were determined using EDTA titration method using plank and sample readings. The results are shown in Table 2.

It can be seen that Sodium and potassium concentrations are $28.93 \pm 6.85,2.53 \pm 0.43 \mathrm{mg} / \mathrm{kg}$, respectively. The high concentration of sodium or potassium ion in sludge samples may be attributed to the fact that a lot of surfactants, cosmetics, and soups are containing sodium or potassium in their chemical structure. Moreover, calcium and magnesium concentrations are $271 \pm 38.74$ and $177 \pm 67 \mathrm{mg} / \mathrm{kg}$, respectively. Furthermore, Fe concentration is $125.12 \pm 13.65 \mathrm{mg} / \mathrm{kg}$.

As obvious, $\mathrm{K}$ is the lowest concentration among all of the cations and $\mathrm{Ca}$ is the highest concentration among all cases.

The explanation of these results is that surfactants, soups, and cosmetics may be degraded during sludge formation resulting in transferring sodium or potassium into inorganic form (e.g. $\mathrm{NaCl}$ ). Our explanation is supported by the results of [19] who found that surfactant, cosmetic product formulations, contributes significantly to the pollution profile of sewage and wastewater with various compounds including cations. Further supports to our results come from [20] who reported high concentration of cations in treated sewage water and from the results of [21] who correlated the high concentrations of cations in aerobic granular sludge with the low concentration of $\mathrm{Cu}^{++}$in sludge.

\subsection{Concentrations of Anions}

Chloride concentration in sludge samples was determined according to the titration method using $\mathrm{AgNO}_{3}$ and $\mathrm{NaCl}$ as standard materials. The relationship between $\mathrm{Cl}$ concentrations and $\mathrm{AgNO}_{3}$ concentrations is shown in 
Figure 3. It can be seen that a linear regression equation provide the best fit $\left(\mathrm{R}^{2}=0.9803\right)$. The high value of $\mathrm{R}^{2}$ suggests the best fit, accordingly the regression equation was used to determine the concentration of $\mathrm{Cl}^{-}$ions in the unknown samples. The determined $\mathrm{Cl}^{-}$concentrations in the unknown samples are shown in Table 3.

It is obvious that a linear relationship is shown in concentration at $\mathrm{AgNO}_{3}$ below $4 \mathrm{mg} / \mathrm{l}$ with an equation of $\mathrm{Y}$ $=0.2996 \mathrm{X}-0.0106$ with a value of $\mathrm{R}^{2}=0.9803$ indicating a strong positive association between the $\mathrm{Cl}(\mathrm{ml})$ and $\mathrm{Na}$ concentration $\mathrm{mg} / \mathrm{l}$. Accordingly, in the range of $0-4 \mathrm{mg} / \mathrm{l}$, concentration of $\mathrm{Cl}$ may be determined. However, concentration above this range may need several dilutions. Nevertheless, within the range, a strong positive association was observed $\mathrm{R}^{2}=0.9803$. This relationship provides good fits that allow determination of $\mathrm{Cl}$ concentration in the sludge sample. However, the determined $\mathrm{Cl}$ concentration is $25.84 \pm 4.26 \mathrm{mg} / \mathrm{kg}$ (Table 3) which is in the acceptable levels of $\mathrm{Cl}$ standards [22].

\subsubsection{Sulfate Concentration}

The relationship between the optical density and sulfate concentration are linear below $60 \mathrm{mg} / \mathrm{l}$ as shown in Figure 4.

It can be seen that the relationship is expressed as a linear regression with equation $\mathrm{Y}=0.035 \mathrm{X}+0.066$ and $\mathrm{R}^{2}$ value equals to 0.9971 . This indicates a strong positive association and enabled accurate determination of sulfate concentration in the sludge samples. According, the determined sulfate concentration in sludge equals to

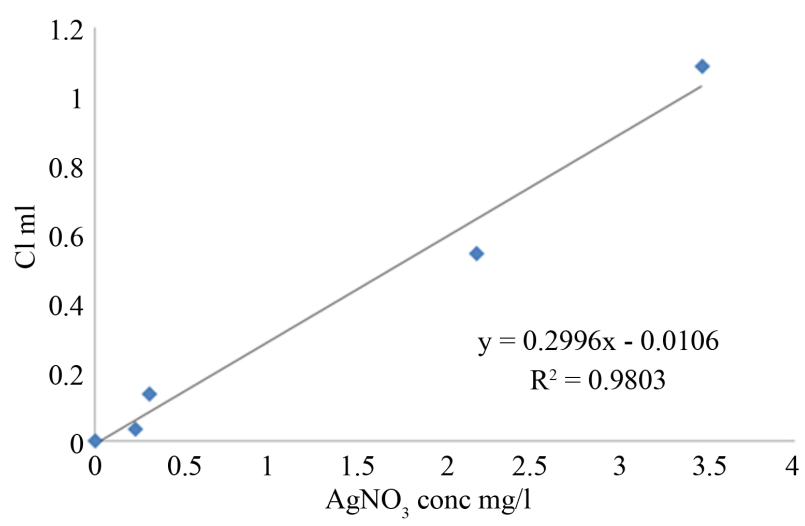

Figure 3. Relationship of standard solutions of $\mathrm{Cl}$ concentration and required amount of $\mathrm{AgNO}_{3}$.

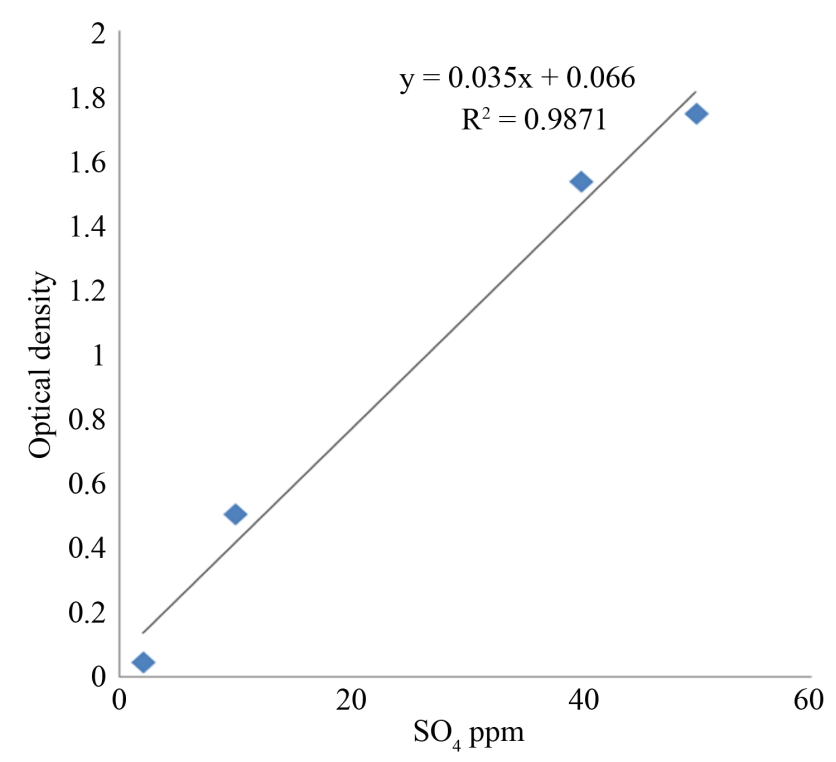

Figure 4. Standard curve of sulfate concentration. 
Table 3. Chloride, sulfate and phosphate concentrations. Values represent average and standard deviation.

\begin{tabular}{cc}
\hline Anion & Average \\
$\mathrm{Cl}^{-}(\mathrm{mg} / \mathrm{kg})$ & $25.84 \pm 4.26$ \\
$\mathrm{SO}_{4}^{2-} \quad(\mathrm{g} / \mathrm{kg})$ & $18.59 \pm 2.44$ \\
$\mathrm{PO}_{4}^{3-} \quad(\mathrm{g} / \mathrm{kg})$ & $0.434 \pm 0.023$ \\
\hline
\end{tabular}

$18.59 \pm 2.44 \mathrm{~g} / \mathrm{kg}$. This value looks nearly high but in fact sulfur containing protein is a high fraction in nature. However, the nearly high sulfate level is due to the high solubility in water which is not pH-dependent. Similar results were recently obtained by [23].

\subsubsection{Phosphate Concentration}

The relationship between gradient concentrations of phosphates and corresponding optical densities are shown in Figure 5.

It can be seen that a linear relation is observed at concentrations below $10 \mathrm{ppm}$ and the relationship is expressed by the equation $\mathrm{Y}=0.3157 \mathrm{X}+0.2313$ with an $\mathrm{R}^{2}$ value equals to 0.9719 . This indicates a strong positive association which enabled determination of phosphate concentrations in the sludge samples. The data are shown in Table 3.

A comparison among anions concentrations is shown in Table 3, it can be seen that $\mathrm{Cl}^{-}$has the lowest concentrations among all whereas $\mathrm{SO}_{4}^{2-}$ is the highest among all.

The explanation of these results is that these values represent the soluble fraction of $\mathrm{Cl}^{-}, \mathrm{SO}_{4}^{2-}$, and $\mathrm{PO}_{4}^{-}$in sludge samples. The low value of phosphate concentrations in sludge samples is due to the fact that, phosphate solubility is $\mathrm{pH}$-dependent. Accordingly, at low $\mathrm{pH}$ value high phosphate levels may be found in sludge. However, the current $\mathrm{pH}$ value of sludge equals to $6.78 \pm 0.02$ [24] accordingly, low fraction of phosphate was found. Another support to our argument comes from the fact that phosphoric acid is a weak acid and has 3 dissociation constants. This indicates that phosphate solubility is $\mathrm{pH}$-dependent. It is obvious that the phosphate level is $0.434 \pm 0.023 \mathrm{~g} / \mathrm{kg}$ in the sludge. As obvious, nearly low values of $\mathrm{PO}_{4}^{3-}$ are available in sludge samples. This value represent only the soluble fraction of phosphate not all phosphate. Under $\mathrm{pH}$ value 6.78, phosphate ion tends to precipitate from the solution. Similar observations were given recently by [25].

\subsubsection{Nitrate, Ammonium and TKN Concentrations}

The importance of nitrate levels in sludge samples emerged from the fact that sludge can be used as an alternative source of nitrate instead of nitrogen, phosphorus and potassium fertilizer application in agriculture.

According to the methods described above, we generated a standard nitrate curve by converting the nitrate into the corresponding nitro-salicylic acid that has yellow color at alkali media and measured the optical density at $410 \mathrm{~nm}$. Accordingly, the optical density of nitro-salicylic acid and its gradient concentrations are shown in Figure 6.

It is obvious that a linear relationship with a value of $\mathrm{R}^{2}=0.9988$ is obtained even at nearly high nitrate concentration $(500 \mathrm{mg} / \mathrm{l})$. This suggests that a strong positive association exists between the optical density and tested concentrations. This linear mode of interaction enabled us to use the regression equation to determine nitrate concentrations in the unknown samples of sludge. Accordingly, the linear relationship is expressed by the equation $\mathrm{Y}=0.0008 \mathrm{X}$. This equation was used to determine the nitrogen concentration in the sludge samples. The value of nitrate level in sludge equals to $871 \pm 135 \mathrm{mg} / \mathrm{kg}$ sludge as shown in Table 4 .

The nitrate level tends to be high. The explanation of this result is probably due to drying sludge, re-concentration of cations and anions may occur beside the fact that ammonium hydroxide may be converted to nitrate due to high $\mathrm{O}_{2}$ contents due to drying process. This explanation is supported by the results of [26] who investigated the nitrification performance in a membrane bioreactor treating industrial wastewater and concluded that mixing the municipal waste water with industrial waste water in the level up to $50 \%$ resulted in a breakdown of nitrification process. However, this level of nitrate is sufficient for plant nutrition. Furthermore, Total Kjeldahl Nitrogen (TKN) is nearly high and equals to $5000.04 \pm 757.5 \mathrm{mg} / \mathrm{kg}$ sludge (Table 4). This high value presents all fractions of organic nitrogen. Our results agree with [27] who indicated that digested sewage sludge had high value of total nitrogen $(2.17 \% \pm 0.07 \%)$. 


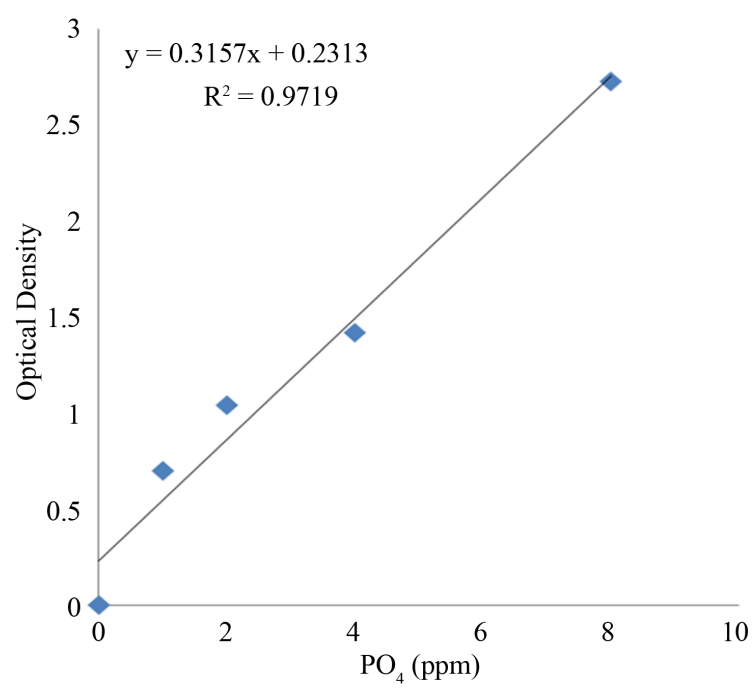

Figure 5. Standard curve of phosphate determination in sludge samples.

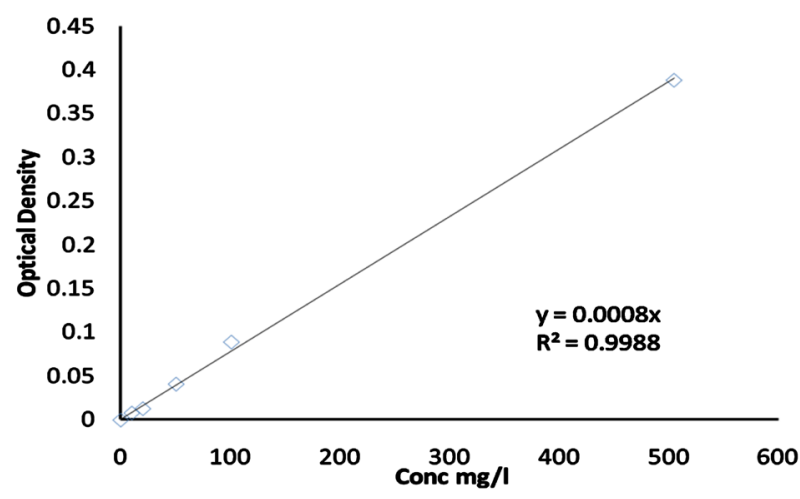

Figure 6. Optical density nitrate concentration relationship. Standard curve.

Table 4. Nitrogen levels in sludge. Values represent average and standard deviation.

\begin{tabular}{cc}
\hline & Sludge \\
\hline TKN mg/kg & $5000.04 \pm 757.5$ \\
Total soluble N mg/l & $61.63 \pm 31.69$ \\
Nitrate $\mathrm{mg} / \mathrm{kg}$ & $871 \pm 135$ \\
\hline
\end{tabular}

The value of Total Kjeldahl Nitrogen (TKN) of the sludge is $5000.04 \pm 757.5 \mathrm{mg} / \mathrm{kg}$. The explanation of high TKN value is that sludge originated from human feces which contain a high fraction of protein due to high consumption of protein. It has been estimated that protein consumption per capita per day in Gaza Strip ranged between $20-40 \mathrm{~g} / \mathrm{capita} / \mathrm{day}$. High fraction of this protein goes to the wastewater treatment plant and end up by sludge samples. Accordingly, high fraction of total Nitrogen was observed in sludge samples. Moreover, the total soluble nitrogen is $61.63 \pm 31.69 \mathrm{mg} / \mathrm{l}$, regardless of the high value of standard deviation; the total soluble nitrogen is nearly in the expected range. This includes ammonia, amines and amino-acids. Recent papers showed similar results [28]. This value of total soluble $\mathrm{N}$ is considered moderate level. However, the explanation of this result is that all nitrogen fractions in wastewater or sludge are present in the form of organic nitrogen or in the reduced form $\left(\mathrm{NH}_{3}, \mathrm{NH}_{4} \mathrm{OH}\right)$ due to the anaerobic condition of TWW or sludge. Accordingly, moderate to low values of soluble $\mathrm{N}$ may be found. Our results are also supported by the previous work of [29] who found low nitrate concentration in the treated wastewater. 


\subsection{Concentration of Heavy Metals}

Concentration of heavy metals in sludge samples are shown in Table 5. It can be seen that cupper concentration is $172.56 \pm 61.53 \mathrm{mg} / \mathrm{kg}$. Moreover, lead concentration is $75.86 \pm 1.63 \mathrm{mg} / \mathrm{kg}$. Furthermore, the zinc concentration is $218.73 \pm 8.35 \mathrm{mg} / \mathrm{kg}$. The manganese concentration is $157.96 \pm 21.67 \mathrm{mg} / \mathrm{kg}$. It is obvious that Zn concentration is the highest one among all cases followed by cupper and manganese. Moreover, lead concentration is the lowest one among all.

The high levels of heavy metals can be explained by the fact that industrial wastewater network is connected with the domestic wastewater network. Both wastewaters come together to wastewater treatment plant. The mixing of industrial wastewater with domestic wastewater allows heavy metals to precipitate due to the changes of $\mathrm{pH}$ values from acidic range in the industrial wastewater to alkaline range in the domestic wastewater. The precipitated heavy metals react with organic acid that generated from the biodegradation of the organic wastes in the treatment plant and with inorganic acid.

This process makes an accumulation of heavy metals in sludge. Our explanation is supported by the results of [30] who investigated the distribution and variation trend of heavy metals in sludge samples collected from different wastewater treatment plants in China and showed that contents of heavy metals in sludge varied significantly, and the average contents exhibited an order of $\mathrm{Cr}>\mathrm{Zn}>\mathrm{Cu}>\mathrm{Pb}>\mathrm{As}>\mathrm{Hg}>\mathrm{Cd}$. However, the presence of heavy metal in sludge sample may move to the plant during the agricultural process [29]. Furthermore, the presence of heavy metals in sludge may become toxic to soil nitrifying or denitrifying bacteria that benefit the plant growth. This explanation is supported by the results of [31] who studied the effects of heavy metals in wastewater on anoxic/aerobic-membrane bioreactors performance and revealed that the nitrification/denitrification rates were dramatically decreased in different percentages based on the concentration of heavy metals in wastewater. Accordingly, it may be necessary and recommended to remove heavy metals from sludge samples before agricultural application. Our recommendation is supported by the work of [32] who investigated the long-term removal of heavy metals in a combined up-flow anaerobic sludge bed system treating municipal wastewater and revealed that high removal efficiencies were found for some metals in the following order: Sn $>$ $\mathrm{Cr}>\mathrm{Cu}>\mathrm{Pb}>\mathrm{Zn}>\mathrm{Fe}(63 \%$ - 94\%) and medium removal efficiencies for Ni (49\%), Hg (42\%), and Ag (40\%), and finally $\mathrm{Mn}$ and As showed negative percentage removals. Further support come from the results of [33] who studied the retention of heavy metals at two pilot-scale treatment wetlands, consisting of two vertical flow beds followed by a horizontal flow bed and revealed that a major removal pathway was sedimentation and adsorption onto soil substrate as well as precipitation and co-precipitation. It has been shown by [34] that application of compost containing high fraction of heavy metals expose plant and ground water to contamination of heavy metals. In addition, El-Nahhal [20] found heavy metals in the drinking water collected from different sources and attributed this to possible contamination from industrial wastewater out house. In comparison with USEPA 1994 standards, the heavy metals concentrations in the sludge are found to be many times lower than USEPA 1994 standards. Accordingly, the sludge can be used in agriculture.

\section{Conclusion}

Sludge samples contain high fraction of $\mathrm{Na}, \mathrm{K}, \mathrm{Ca}, \mathrm{Mg}$, and Fe which are in respective manner $28.93 \pm 6.85$, $2.53 \pm$ 0.43, $271 \pm 38.74,177 \pm 67$ and $125.12 \pm 13.65 \mathrm{mg} / \mathrm{kg}$. Moreover, $\mathrm{PO}_{4}^{3-}, \mathrm{SO}_{4}^{2-}, \mathrm{Cl}^{-}$are respectively $25.84 \pm 4.26 \mathrm{mg} / \mathrm{kg}, 18.59 \pm 2.44 \mathrm{~g} / \mathrm{kg}$ and $0.434 \pm 0.023 \mathrm{~g} / \mathrm{kg}$. Sludge samples contained high fraction of

Table 5. Heavy metals levels in sludge. Values represent average and standard deviation (mg/kg).

\begin{tabular}{ccc}
\hline Heavy metals & Average \pm stdev $(\mathrm{mg} / \mathrm{kg})$ & USEPA standards $(\mathrm{mg} / \mathrm{kg})$ \\
\hline $\mathrm{Cu}$ & $172.56 \pm 61.53$ & 4300 \\
$\mathrm{~Pb}$ & $75.86 \pm 1.63$ & 840 \\
$\mathrm{Zn}$ & $218.73 \pm 8.35$ & 7500 \\
$\mathrm{Mn}$ & $157.96 \pm 21.67$ & NA \\
\hline
\end{tabular}

NA = not available. 
TKN. Total soluble $\mathrm{N}$ and nitrate are in respective form: $5000.04 \pm 757.5,61.63 \pm 31.69$ and $871 \pm 135 \mathrm{mg} / \mathrm{kg}$. The concentrations of $\mathrm{Cu}, \mathrm{Pb}, \mathrm{Zn}, \mathrm{Mn}$ are in the following order: $172.56 \pm 61.53,75.86 \pm 1.63,218.73 \pm 8.35$ and $157.96 \pm 21.67 \mathrm{mg} / \mathrm{kg}$, respectively. Application of sludge in agriculture soil may enhance plant growth due to high fraction of plant nutrients.

\section{References}

[1] Palestinian Central Bureau of Statistics (2014) Population in Palestine, Household Budget. http://www.pcbs.gov.ps/site/881/default.aspx\#Population

[2] Miller, M.C. (2011) Microbiological Safety of Organic Fertilizers Used for Production. MSC Thesis, Clemson University, Clemson.

[3] Melo, W.J., Marques, M.O., Ferreira, M.E., Melo, G.M.P. and Melo, V.P. (2002) Chemical Properties and Enzyme Activity in a Sewage Sludge Treated Soil. Communications in Soil Science and Plant Analysis, 33, 1643-1650. http://dx.doi.org/10.1081/CSS-120004305

[4] Hue, N.V. (1988) Residual Effects of Sewage Sludge Application on Plant and Soil-Profile Chemical Composition. Communications in Soil Science and Plant Analysis, 19, 1633-1643. http://dx.doi.org/10.1080/00103628809368040

[5] Silveira, M.L.A., Alleoni, L.R.F. and Guilhermje, L.R.G. (2003) Sewage Sludge and Heavy Metals in Soils. Scientia Agricola, 60, 793-806. http://dx.doi.org/10.1590/S0103-90162003000400029

[6] Casado-Vela, J., Sellés, S., Díaz-Crespo, C., Navarro-Pedreño, J., Mataix-Beneyto, J. and Gómez, I. (2007) Effect of Composted Sewage Sludge Application to Soil on Sweet Pepper Crop (Capsicum annuum var. annuum) Grown under Two Exploitation Regimes. Waste Management, 27, 1509-1518. http://dx.doi.org/10.1016/j.wasman.2006.07.016

[7] Roig, N., Sierra, J., Martí, E., Nadal, M., Schuhmacher, M. and Domingo, J. (2012) Long-Term Amendment of Spanish Soils with Sewage Sludge: Effects on Soil Functioning. Agriculture, Ecosystems \& Environment, 158, 41-48. http://dx.doi.org/10.1016/j.agee.2012.05.016

[8] Sterritt, R.M. and Lester, J.N. (1980) The Value of Sewage Sludge to Agriculture and Effects of the Agricultural Use of Sludges Contaminated with Toxic Elements: A Review. Science of the Total Environment, 17, 55-90. http://dx.doi.org/10.1016/0048-9697(80)90102-3

[9] Egiarte, G., Pinto, M., Ruíz-Romera, E. and Camps Arbestain, M. (2008) Monitoring Heavy Metal Concentrations in Leachates from a Forest Soil Subjected to Repeated Applications of Sewage Sludge. Environmental Pollution, 156, 840-848. http://dx.doi.org/10.1016/j.envpol.2008.05.025

[10] Wong, J.W.C., Li, K.L., Zhou, L.X. and Selvam, A. (2007) The Sorption of Cd and Zn by Different Soils in the Presence of Dissolved Organic Matter from Sludge. Geoderma, 137, 310-317. http://dx.doi.org/10.1016/j.geoderma.2006.08.026

[11] Khan, M. and Scullion, J. (2002) Effects of Metal (Cd, Cu, Ni, Pb or Zn) Enrichment of Sewage-Sludge on Soil Micro-Organisms and Their Activities. Applied Soil Ecology, 20, 145-155. http://dx.doi.org/10.1016/S0929-1393(02)00018-5

[12] Serna, M.D. and Pomares, F. (1992) Nitrogen Mineralization of Sludge-Amended Soil. Bioresource Technology, 39, 285-290. http://dx.doi.org/10.1016/0960-8524(92)90218-M

[13] López-Valdez, F., Fernández-Luqueño, F., Luna-Guido, M., Marsch, R., Olalde-Portugal, V. and Dendooven, L. (2010) Microorganisms in Sewage Sludge Added to an Extreme Alkaline Saline Soil Affect Carbon and Nitrogen Dynamics. Applied Soil Ecology, 45, 225-231. http://dx.doi.org/10.1016/j.apsoil.2010.04.009

[14] Fytianos, K. and Charantoni, E. (1998) Leaching of Heavy Metals from Municipal Sewage Sludge. Environment International, 24, 467-475. http://dx.doi.org/10.1016/S0160-4120(98)00026-9

[15] Moreno, J., Hernández, T., Pérez, A. and García, C. (2002) Toxicity of Cadmium to Soil Microbial Activity: Effect of Sewage Sludge Addition to Soil on the Ecological Dose. Applied Soil Ecology, 21, 149-158. http://dx.doi.org/10.1016/S0929-1393(02)00064-1

[16] Saña, J., Giró, F., Soliva, M. and Florensa, P. (1989) Methodology Used for Evaluating the Quality of Compost Produced in Catalonia. Simposio Internazionale produzione et impiego del compost, Adige, 20-23 June 1989, 343-362.

[17] Bashour, I. and Sayegh, A. (2007) Methods of Analysis for Soils of Arid and Semi-Arid Regions. FAO, Rome.

[18] Cataldo, D.A., Maroon, M., Schrader, L.E. and Youngs, V.L. (1975) Rapid Colorimetric Determination of Nitrate in Plant Tissues by Nitration of Salicylic Acid. Communications in Soil Science and Plant Analysis, 6, 71-80. http://dx.doi.org/10.1080/00103627509366547

[19] Ambily, P.S. and Jisha, M.S. (2012) Biodegradation of Anionic Surfactant, Sodium Dodecyl Sulphate by Pseudomonas Aeruginosa MTCC 10311. Journal of Environmental Biology, 33, 717-720. 
[20] El-Nahhal, Y. (2006) Contamination of Goundwater with Heavy Metals in Gaza Strip. 10th International Water Technology Conference, IWTC10 2006, Alexandria, 1139.

[21] Zheng, X.Y., Wang, X.N., Huang, X., Chen, Q., Chen, W. and He, Y.J. (2013) Effects of Cu ${ }^{2+}$ on Morphological Structure, Functional Groups, and Elemental Composition of Aerobic Granular Sludge. Environmental Technology, 34, 219-224. http://dx.doi.org/10.1080/09593330.2012.689368

[22] USEPA (US Environmental Protection Agency) (2010) Guidance for Federal Land Management in the Chesapeake Bay Watershed. USEPA, Washington DC, 841-R-10-002.

[23] Jing, Z., Hu, Y., Niu, Q., Liu, Y., Li, Y.Y. and Wang, X.C. (2013) UASB Performance and Electron Competition between Methane-Producing Archaea and Sulfate-Reducing Bacteria in Treating Sulfate-Rich Wastewater Containing Ethanol and Acetate. Bioresource Technology, 137, 349-357. http://dx.doi.org/10.1016/j.biortech.2013.03.137

[24] El-Nahhal, I.Y., Al-Najar, H. and El-Nahhal, Y. (2014) Physicochemical Properties of Sewage Sludge from Gaza. International Journal of Geosciences, 5, 586-594. http://dx.doi.org/10.4236/ijg.2014.56053

[25] Luan, J., Li, R., Zhang, Z., Li, Y. and Zhao, Y. (2013) Influence of Chlorine, Sulfur and Phosphorus on the Volatilization Behavior of Heavy Metals during Sewage Sludge Thermal Treatment. Waste Management \& Research, 31, 10121018. http://dx.doi.org/10.1177/0734242X13493955

[26] Dvořák, L., Svojitka, J., Wanner, J. and Wintgens, T. (2013) Nitrification Performance in a Membrane Bioreactor Treating Industrial Wastewater. Water Research, 47, 4412-4421. http://dx.doi.org/10.1016/j.watres.2013.03.053

[27] Sreesai, S., Peapueng, P., Tippayamongkonkun, T. and Sthiannopkao, S. (2013) Assessment of a Potential Agricultural Application of Bangkok-Digested Sewage Sludge and Finished Compost Products. Waste Management \& Research, 31, 925-936. http://dx.doi.org/10.1177/0734242X13494261

[28] Sheng, Y. and Xing, L. (2013) Organics Removal and Protein Recovery from Wastewater Discharged during the Production of Chondroitin Sulfate. Water Science \& Technology, 68, 1582-1590. http://dx.doi.org/10.2166/wst.2013.405

[29] El-Nahhal, Y., Tubail, K., Safi, M. and Safi, J. (2013) Effect of Treated Waste Water Irrigation on Plant Growth and Soil Properties in Gaza Strip, Palestine. American Journal of Plant Sciences, 4, 1736-1743.

[30] Zhang, C., Chen, H., Yu, Y.X., Wang, L.J., Han, J.B. and Tao, P. (2013) Pollution Characteristics of Heavy Metals in Sludge from Wastewater Treatment Plants and Sludge Disposal in Chinese Coastal Areas. Huan Jing Ke Xue, 34, 1345-1350. (in Chinese)

[31] Feng, B., Fang, Z., Hou, J., Ma, X., Huang, Y. and Huang, L. (2013) Effects of Heavy Metal Wastewater on the Anoxic/Aerobic-Membrane Bioreactor Bioprocess and Membrane Fouling. Bioresource Technology, 142, 32-38. http://dx.doi.org/10.1016/j.biortech.2013.05.019

[32] De la Varga, D., Díaz, M.A., Ruiz, I. and Soto, M. (2013) Heavy Metal Removal in an UASB-CW System Treating Municipal Wastewater. Chemosphere, 93, 1317-1323. http://dx.doi.org/10.1016/j.chemosphere.2013.07.043

[33] Wojciechowska, E. and Gajewska, M. (2013) Partitioning of Heavy Metals in Sub-Surface Flow Treatment Wetlands Receiving High-Strength Wastewater. Water Science \& Technology, 68, 486-493.

[34] Kaschel, A., El Nahhal, Y., Mourad, T.A., Tubail, K., Safi, J., Hadar, Y., Chen, Y. and Römheld, V. (2002) LongTerm Field Experiment to Examine the Agricultural Application of Municipal Solid Waste Compost in the Gaza Strip. 
Scientific Research Publishing (SCIRP) is one of the largest Open Access journal publishers. It is currently publishing more than 200 open access, online, peer-reviewed journals covering a wide range of academic disciplines. SCIRP serves the worldwide academic communities and contributes to the progress and application of science with its publication.

Other selected journals from SCIRP are listed as below. Submit your manuscript to us via either submit@scirp.org or Online Submission Portal.
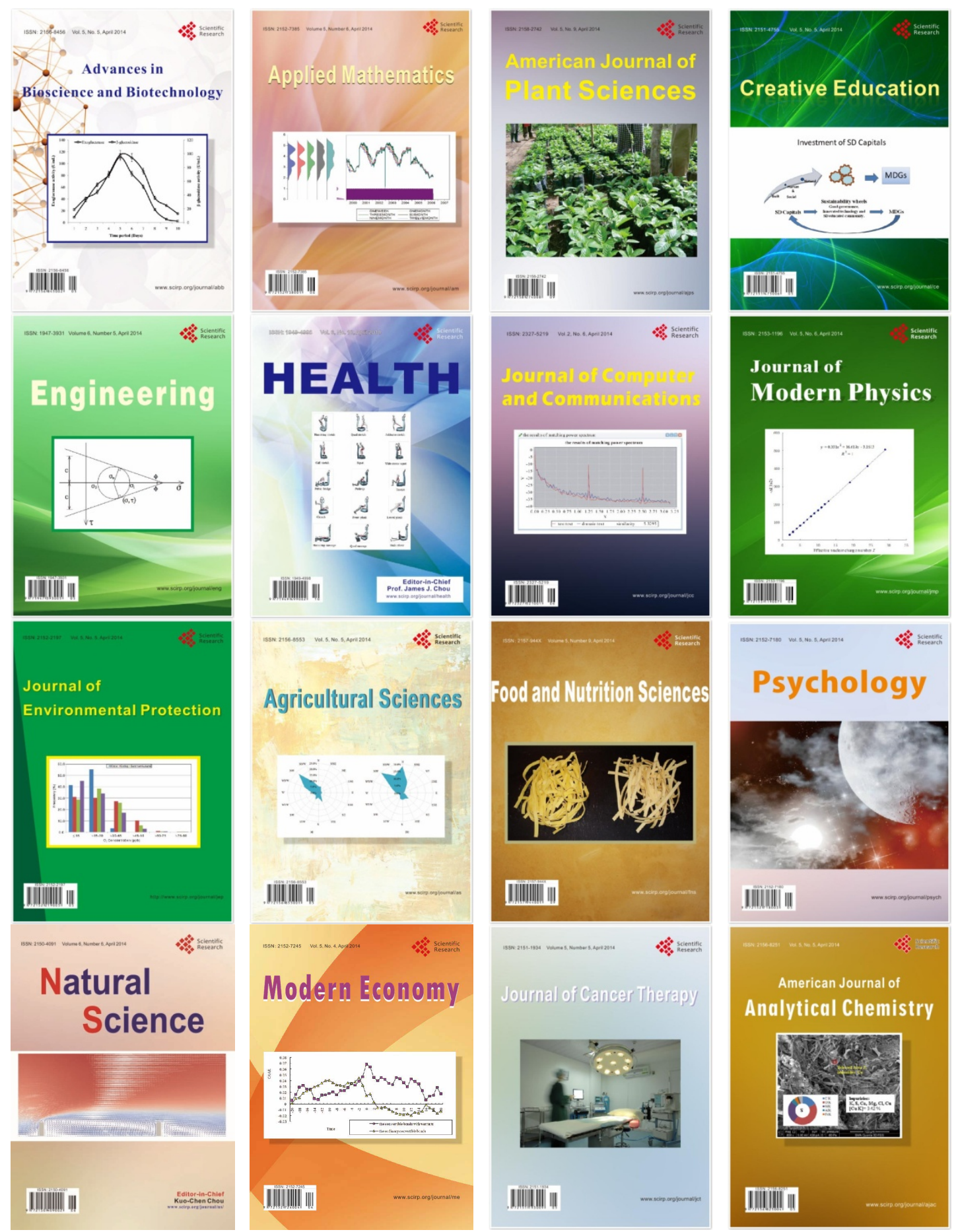